\title{
Corrosión del acero desnudo y galvanizado en yeso
}

\section{Corrosion of bare and galvanized steel in gypsum}

\author{
MERCEDES GOMEZ Y CARMEN ANDRADE \\ IETCC/CSIC \\ Serrano Galvache, s/n, 28033 MADRID/España
}

Fecha de recepción: 3-VI-88

\section{RESUMEN}

El yeso es un material de construcción de relativo bajo coste y que, además, es muy abundante en nuestro pais. Debido a su pH cercano a la neutralidad, cuando entra en contacto con el acero, este puede corroerse a elevadas velocidades. En esta comunicación se presentan los resultados de un estudio sobre la velocidad de corrosión del acero desnudo y galvanizado en contacto con yeso y escayola y la influencia que tienen: el tratamiento térmico del curado del yeso, la humedad relativa ambiental y la adición de aditivos de diversa naturaleza y finalidad.

Como técnicas de medida se han utilizado la medida de la Resistencia de Polarización y de la pérdida de peso, así como observaciones visuales. De los resultados se puede deducir que en ambientes secos el acero galvanizado se comporta siempre mejor que el acero desnudo y que la humedad ambiental afecta en proporción más a la corrosión del galvanizado que a la del desnudo. Los aditivos para el yeso utilizados no modifican estas conclusiones, en cambio tanto los nitritos como la cal mejoran el comportamiento del acero desnudo, mientras que no modifican el del galvanizado. La adición de cal no se recomienda debido a fenómenos de expansión dilatada en el tiempo.

\begin{abstract}
SUMMARY
Gypsum is a relatively low-cost building material much abounding in our country. When it is put in contact with steel, it may produce high corrosion rates due to its $\mathrm{pH}$ value (close to 7). This work reports the results obtained in studying the corrosion rates of bare and galvanized steel in contact with gypsum and plaster, as well as the influence curing thermal treatment applied to gypsum, enviromental relative humidity and addition of compounds with different natures and purposes may have in such process.

In-situ observations, as well as the measurement of the Polarization Resistance and the weight loss have been used as measurement technics. From the results obtained it has been possible to deduce that galvanized steel has better behaviour in dry enviroments than bare steel in the same conditions and moist atmosphere induces proportionally more corrosion in galvanized steel than in bare one. Additions to gypsum do not modified these conclusions, though it may be pointed out that addition of nitrites or lime improves the behaviour of bare steel, while galvanized behaviour is not modified. The addition of lime is not recommended because phenomena of dilated along time expansion may take place.
\end{abstract}

\section{INTRODUCCION}

Las diversas técnicas de cocción del yeso natural permiten obtener diferentes materiales, como yesos y escayolas, clasificados en el Pliego General de Condiciones para la recepción de yesos y escayolas en las obras de construcción RY-85 (1), según su composición y propiedades en los cinco tipos siguientes: yeso grueso $Y G$, yeso fino $Y F$, yeso de prefabricados YP, escayola E-30 y escayola especial E-35.

Las aplicaciones en el campo de la construcción son múltiples. En la actualidad existe un gran interés en incrementar su uso, en especial en los países subdesarrollados o

\section{INTRODUCTION}

Several thermal treatments applied to natural gypsum allow to obtain different materials, such as gypsum and plastes, which are classified according to their composition and properties into five types, following the General Specifications for gypsum and plastes as building materials $R Y-85$ (1): coarse gypsum $Y G$, fine gypsum YF, prefabricated pannels YP, plaster E-30 and special plaster E-35.

Uses in the field of building works are numerous. Due to gypsum low price, its employement is now gaining more and more interest, especially in underdeveloped and 
en vías de desarrollo, por ser el yeso un material de bajo coste.

Por ello resulta importante el estudio de los procesos de corrosión que pueden tener lugar cuando el yeso está en contacto con metales, sobre todo con los más utilizados en construcción como son el acero desnudo y el galvanizado.

En el año 1977 M. FOUCAULT (2) presentó en el Coloquio Internacional de la RILEM un trabajo sobre la corrosión de metales en contacto con yeso, utilizando como técnicas de medida, métodos electroquímicos, entre ellos el de medida de Resistencia de Polarización. Según este estudio, el aluminio y el cobre se comportan bien en el yeso, por el contrario el hierro se corroe fácilmente, pero se puede evitar este fenómeno con un tratamiento previo del metal con pinturas de minio, pinturas a base de PVC o de epoxi, galvanización y adición de cal al yeso.

La técnica de medida de Resistencia de Polarización ha sido utilizada con frecuencia en el estudio del proceso de corrosión de metales embebidos en hormigón, en trabajos llevados a cabo en el Instituto EDUARDO TORROJA (3) y (4).

En el presente trabajo se ha estudiado el proceso de corrosión que sufre el acero desnudo y el galvanizado en contacto con yeso y escayola y la influencia en dicho proceso del tipo de curado, humedad relativa, empleo de aditivos endurecedor y para enfoscado, así como la adición de hidróxido cálcico y nitritos como inhibidores de corrosión. La técnica de medida empleada ha sido la de medida de Resistencia de Polarización, contrastada con medidas gravimétricas y observación visual directa.

\section{METODO EXPERIMENTAL}

\section{Materiales}

Se ha utilizado yeso grueso y escayola E-30 (según clasificación del Pliego PY-85), esta última para ensayos sin aditivos.

Los aditivos que se han utilizado han sido de los siguientes tipos:

a) Un aditivo endurecedor del yeso.

b) Un aditivo para enfoscado.

c) Dos aditivos a base de nitritos $\left[\mathrm{NaNO}_{2}\right.$ y $\mathrm{Ca}\left(\mathrm{NO}_{2}\right)_{2}$ ] para estudiar un posible efecto inhibidor de la corrosión. low-industrialized countries.

For all these reasons it is becoming important the study of corrosion precesses that may take place when gypsum is put into contact with metals, especially for those more often used in building, such as bare and galvanized steel.

In 1977, M. FOUCAULT (2) gave out in the International Conference of RILEM a report on metal corrosion in contact with gypsum by electrochemical methods, such as the measurement of the Polarization Resistance in which were used as measurement technic. According to this study, both aluminium and copper behave well in contact with gypsum, while irom is easily corroded, phenomenon that cann be avoided by preious treatments applied to the metal such as painting with red lead paints or coatines with PVC or epoxi, galvanization and addition of with lime to the gypsum.

Measurement of Polarization Resistance has often been used in studies of corrosion processes in metals embedded in concrete such as those carried out in the EDUARDO TORROJA Institute (3 and 4).

This work has studied the corrosion process ocurred in bare and galvanized steel when they are put into contact with gypsum and plaster, as well as the influence those curring procedures, relative humidity, the use of hardening and stretching additives and addition of calcium hydroxides and nitrites as corrosion inhibitors may have on this process. The the Polarization Resistance measurement has been employed and compared to gravimetrical measurements as well as to those provided by in-situ observations.

\section{EXPERIMENTAL}

\section{Materials}

Coarse gypsum and plaster E-30 (according to the General Specifications mentioned above) have been used. The latter only for tests without any additions.

Folowing types have been used:

a) Hardening additive of gypsum.

b) Stretching additive.

c) Two nitrites made $\left[\mathrm{NaNO}_{2}\right.$ and $\left.\mathrm{Ca}\left(\mathrm{NO}_{2}\right)_{2}\right]$ as possible corrosion inhibitors. 
d) Hidróxido cálcico para inhibir la corrosión mediante aumento del $\mathrm{pH}$.

Se fabricaron probetas de $70 \times 70 \times 70 \mathrm{~mm}$ en las que se embebieron placas de acero desnudo y galvanizado. Se delimitó un área de $2 \mathrm{~cm}^{2}$ tal y como muestra la figura 1 .

Un aspecto de la probeta fabricada se muestra en la figura 2.
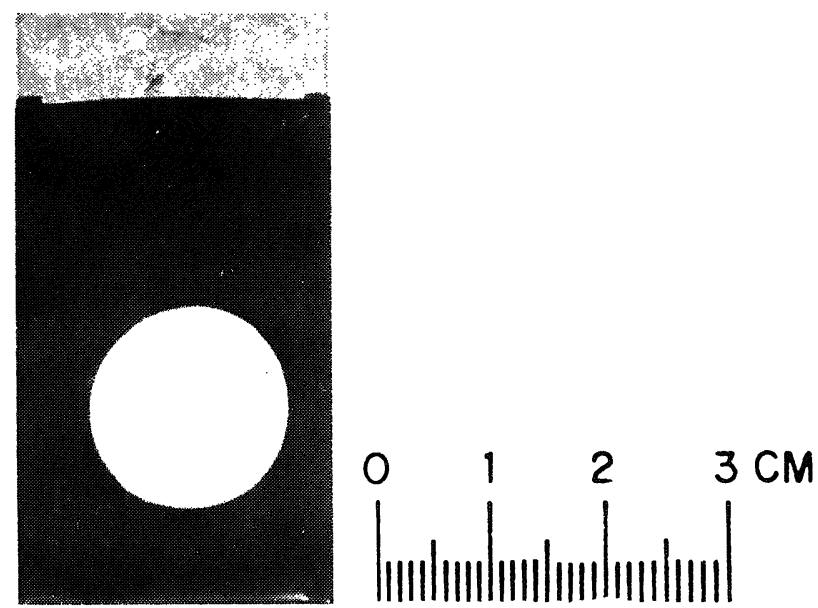

Fig. 1.-Placa de acero utilizada en los ensayos.

Fig. 1.-Steel plate employed during the tests.

\section{AMASADO Y CURADO DE LAS PROBETAS}

Para la preparación se siguió la técnica operatoria descrita en el apartado 6.2 de la norma UNE 102.031.82.

En las primeras amasadas se utilizó la relación agua/yeso 0,8 . En el caso de las amasadas preparadas con adición de aditivo endurecedor y para enfoscados, el final del fraguado tuvo lugar después de dos horas, por lo que se prepararon de nuevo otras probetas con una relación agua/yeso 0,5 , con la que pudo efectuarse el desmoldeo pasada media hora. En el caso de adición de hidróxido cálcico se preparó la amasada sólo con relación agua/yeso 0,5 , seleccionada por determinación de la cantidad de yeso correspondiente al amasado de saturación, según se indica en el apartado 4 de UNE 102.031 .82 , ya que con la relación agua/yeso 0,8 tenía lugar el fraguado antes de treinta minutos, pero quedaba un exceso de agua sobre las probetas ya endurecidas. d) Calcium hydroxide to inhibit corrosion by means $\mathrm{pH}$ increase.

$70 \times 70 \times 70 \mathrm{~mm}$ specimens were made in which plates of bare and galvanized steel were embedded. A $2 \mathrm{~cm}^{2}$ attack surface was delimited as shows Fig. 1. A general view of the specimen is shown in Fig. 2.

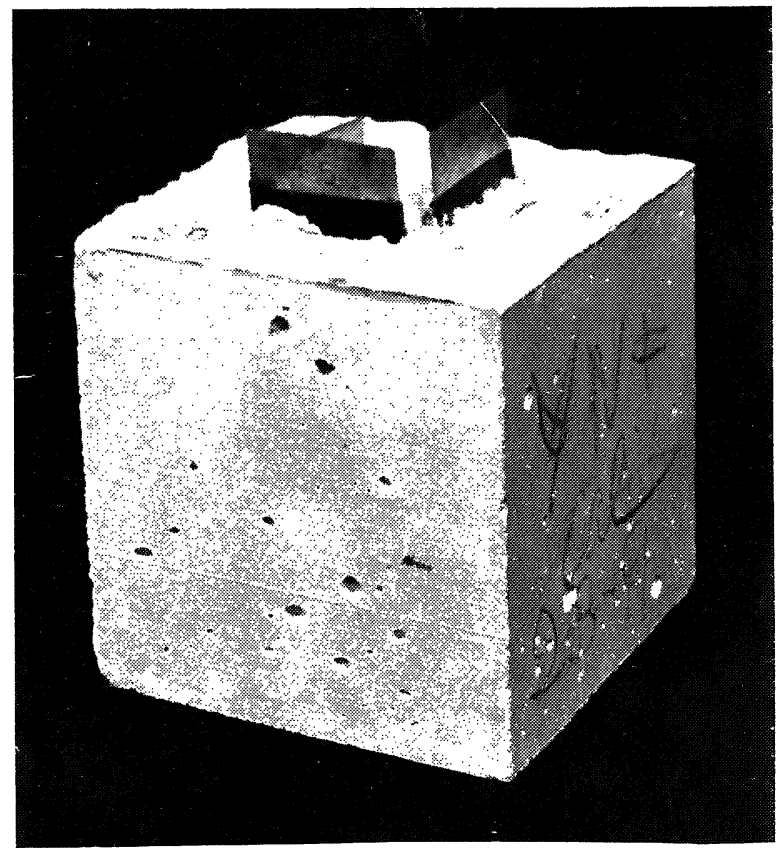

Fig. 2.-Probeta utilizada en los ensayos, en la que pueden observarse las placas embebidas.

Fig. 2.-Specimen employed in the tests, in which the embedde plates can be observed.

\section{Mixing and curing}

The preparation procedures followed the operational technic described in item 6.2 of UNE 102.031.82 standard.

First mixes were prepared with a water/gypsum ratio 0.8 . In mixes containing hardening and stretching additives, the end of the setting process took place after two hours later. New specimens were therefore prepared with a water/gypsum ratio 0.5 , in such a way that it could be removed from the mold after half an hour. When calcium hydroxide was added the mix was prepared only with the water/gypsum ratio 0.5 , which was selected by determination of the amount of gypsum corresponding to saturation according to the specifications given in item 4 of UNE 102.031.82, since for water/gypsum ratio 0.8 , the setting process took place before 30 minutes, but some water remained on the hardened specimens. 
Los curados se efectuaron en algunos casos manteniendo durante cinco días las probetas en cámara a $\mathrm{HR}>90 \%$ y $\mathrm{t}=20 \pm 2{ }^{\circ} \mathrm{C}$, para luego someterlas a un secado en estufa a $42^{\circ}$ $\pm 3^{\circ} \mathrm{C}$ durante dos dias más, según prescribe la UNE 102.031 .82 para la determinación de las resistencias mecánicas. En el resto de los casos se prescindió de este secado brusco y simplemente se mantenian 24 horas en camara húmeda.

Pasado este período las probetas se guardaron hasta un total de 180 días en tres humedades diferentes: $50 \%, 100 \%$ o bien en contacto con papel de filtro humedecido (sobre superficie húmeda S.S.H.).

Todas las condiciones de ensayo se han recogido en la tabla 1 .
In some cases, the curing processes were carried out keeping the specimens in a chamber at $\mathrm{RH}>90 \%$ during five days and at $T=20 \pm 2^{\circ} \mathrm{C}$ followed by drying in an oven at $42 \pm 3^{\circ} \mathrm{C}$ during two additional days, according to the specifications given in UNE 102.031.82 for determination of mechanical resistances. In the other cases, this sudden drying was avoided and the specimens were simply kept in moist chamber during 24 hours.

After this period, the specimens were kept in three diferent moist atmosphere during 180 days: $50 \%, 100 \%$ or in contact with moist filtre paper (on a moist surface S.S.H.).

All test conditions are shown in Table 1.

$\begin{array}{llll}\text { TABLA } & 1 \quad \text { (TABLE } & 1\end{array}$

\begin{tabular}{|c|c|c|c|c|c|c|c|c|c|}
\hline & \multirow{2}{*}{$\begin{array}{c}\text { Clave } \\
\text { utilizada } \\
\text { enfiguras } \\
\text { (Figure } \\
\text { key) }\end{array}$} & \multirow{2}{*}{$\begin{array}{l}A / C \\
(W / C)\end{array}$} & \multirow{2}{*}{$\begin{array}{c}\text { Curado } \\
42^{\circ} \mathrm{C} \\
\left(\mathrm{Curing}^{\circ} \text { at }\right. \\
\left.42^{\circ} \mathrm{C}\right)\end{array}$} & \multicolumn{2}{|c|}{$\begin{array}{c}\text { Valorcte. } \\
50 \% \mathrm{HR} \\
\text { (Constant }{ }^{2} \text { value } \\
50 \% \mathrm{HR} \text { ) }\end{array}$} & \multicolumn{2}{|c|}{$\begin{array}{c}\text { Valor cte. B } \\
100 \% \mathrm{HR} \\
\text { (Constant B value } \\
100 \% \mathrm{HR} \text { ) }\end{array}$} & \multicolumn{2}{|c|}{$\begin{array}{c}\text { Valor cte. B } \\
\text { S.S.H. } \\
\text { (Constant B Balue } \\
\text { S.S. H.) }\end{array}$} \\
\hline & & & & $\begin{array}{l}\text { Acero } \\
\text { negro } \\
\text { (Bare } \\
\text { steel) }\end{array}$ & $\begin{array}{l}\text { Acero } \\
\text { galv. } \\
\text { (Gaalv. } \\
\text { steel) }\end{array}$ & $\begin{array}{l}\text { Acero } \\
\text { negro } \\
\text { (Bare } \\
\text { steel) }\end{array}$ & $\begin{array}{l}\text { Acero } \\
\text { galv. } \\
\text { (Gaalv. } \\
\text { steel) }\end{array}$ & $\begin{array}{l}\text { Acero } \\
\text { negro } \\
\text { (Baire } \\
\text { steel) }\end{array}$ & $\begin{array}{l}\text { Acero } \\
\text { galv. } \\
\text { (Galv. } \\
\text { steel) }\end{array}$ \\
\hline $\begin{array}{l}\text { Yeso grueso } \\
\text { (Coarse gypsum) }\end{array}$ & 1 & 0,8 & no & 260 & 52 & 52 & 52 & - & - \\
\hline $\begin{array}{l}\text { Yeso grueso } \\
\text { (Coarse gypsum) }\end{array}$ & $1 \mathrm{a}$ & 0,8 & si & 260 & 52 & 910 & 52 & - & - \\
\hline $\begin{array}{l}\text { Escayola E-30 } \\
\text { (PlasterE-30) }\end{array}$ & $2 a$ & 0,8 & si & - & - & 1.820 & 52 & 4 & 26 \\
\hline $\begin{array}{l}\text { Aditivo endurecedor } \\
\text { (Hardener additive) }\end{array}$ & 3 & 0,8 & no & 260 & 52 & 260 & 52 & - & - \\
\hline $\begin{array}{l}\text { Aditivo endurecedor } \\
\text { (Hardener additive) }\end{array}$ & $3 b$ & 0,5 & no & 260 & 52 & 104 & 52 & - & - \\
\hline $\begin{array}{l}\text { Aditivo enfoscado } \\
\text { (Stretching additive) }\end{array}$ & 4 & 0,8 & no & 260 & 52 & 320 & 52 & - & - \\
\hline $\begin{array}{l}\text { Aditivo enfoscado } \\
\text { (Stretching additive) }\end{array}$ & $4 b$ & 0,5 & no & 520 & 26 & 130 & 52 & - & - \\
\hline $2 \% \mathrm{NaNO}_{2}$ & 5 & 0,8 & no & 104 & 52 & 1.040 & 78 & 52 & 52 \\
\hline $2 \% \mathrm{Ca}\left(\mathrm{NO}_{2}\right)_{2}$ & 6 & 0,8 & no & - & - & 520 & 104 & - & - \\
\hline $5 \% \mathrm{Ca}(\mathrm{OH})_{2}$ & 7 & 0,5 & no & 10.400 & 130 & 10.400 & 130 & 104 & 104 \\
\hline $5 \% \mathrm{Ca}(\mathrm{OH})_{2}$ & $7 a$ & 0,5 & si & - & - & - & - & 130 & 130 \\
\hline
\end{tabular}

Variables experimentales adoptadas así como valores de la constante $\mathrm{B}$ de la fórmula de Stein utilizados para el cálculo y representación de la $\mathrm{i}_{\text {corr }}$ Experimental variables adopted and values of constant $B$ in stein formula employed for calculation and drowing of $i_{\text {corr }}$

\section{TECNICAS DE MEDIDA}

La Resistencia de Polarización permite evaluar la velocidad de corrosión instantánea de un metal en un medio determinado (6) sin alterar de una manera apreciable el proceso de corrosión existente. Para ello se impone al potencial de corrosión de la parte metálica un

\section{Measurement technics}

The Polarization Resistance allows to evaluate the instantaneous corrosion rate of a metal in a given medium (6) without altering noticeably the existing corrosion process. For such evaluation, a small increment ( $\pm 10 \mathrm{mV}$ ) is applied to the corrosion potential of the 
pequeño incremento de $\pm 10 \mathrm{mV}$ y se mide a continuación la intensidad de la corriente inducida.

Según la ecuación de Stern y Geary (7) metallic part and then, the intensity of the induced current is measured.

According to the equation of Stern and Geary (7).

$$
i_{\text {corr }}=\frac{B}{R_{p}}=B\left(\frac{\Delta I}{\Delta E}\right)_{\Delta E \rightarrow 0}
$$

Los valores de B utilizados en este trabajo son los indicados en las columnas finales de la tabla 1.

Los valores de $B$ se corrigieron en cada medida mediante el contraste con la pérdida gravimétrica sufrida durante el proceso de corrosión.

El valor de la pérdida de peso electroquímico se calculó al aplicar la ley de Faraday a la intensidad de corrosión del proceso, obtenida al integrar la curva i-t.
Final columns of Table 1 show the $B$ values employed in this work.

$B$ values were corrected for each measurement by comparing them to the gravimetric loss found during the corrosion process.

The electrochemical weight loss was calculated applying the Faraday Law to the corrosion intensity of the process, and obtained integrating the i-t curve.

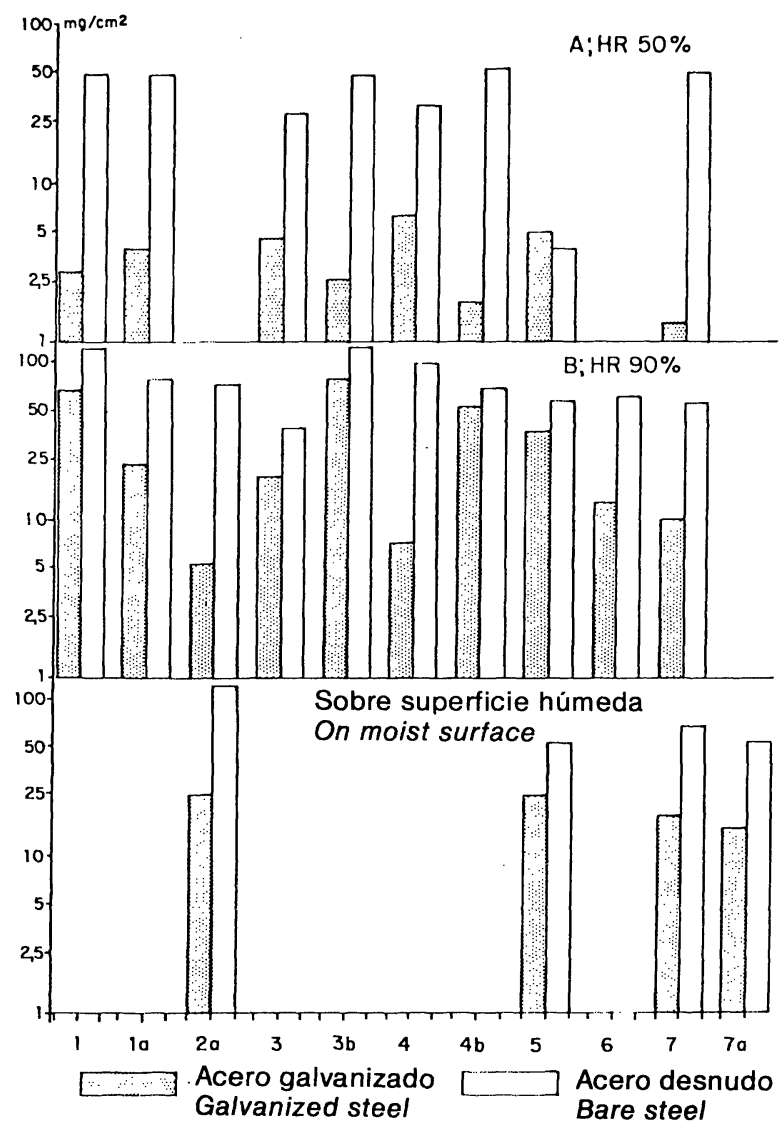

Fig. 3.-Pérdidas gravimétricas de los aceros embebidos en las diferentes probetas, en función de las condiciones de ensayo. Para su identificación véase la clave en la tabla 1.

Fig. 3.-Gravimetric losses of steel embedded in different specimens, as a function of test conditions. See identification see key on Tab. 1. 

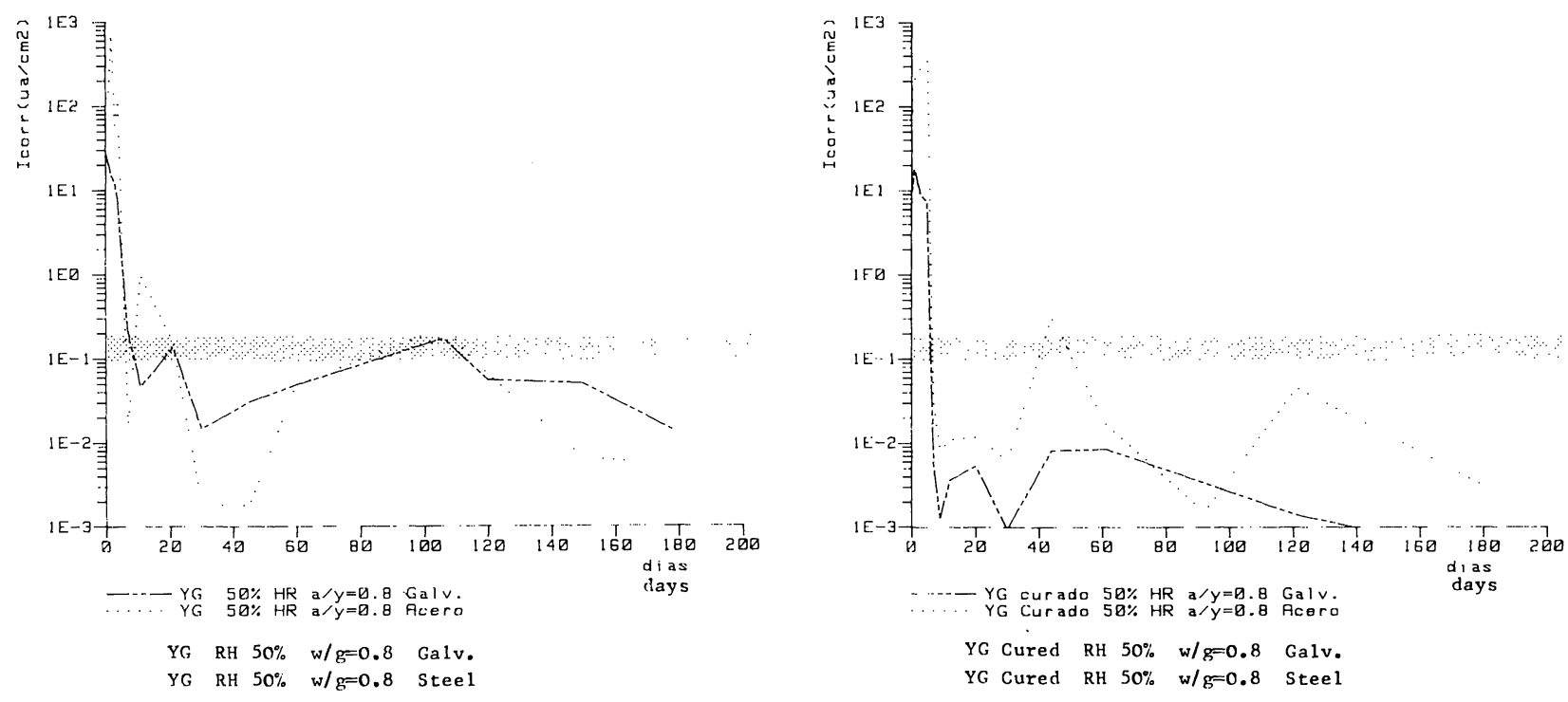

YG RH $50 \% \quad w / g=0.8$ Steel
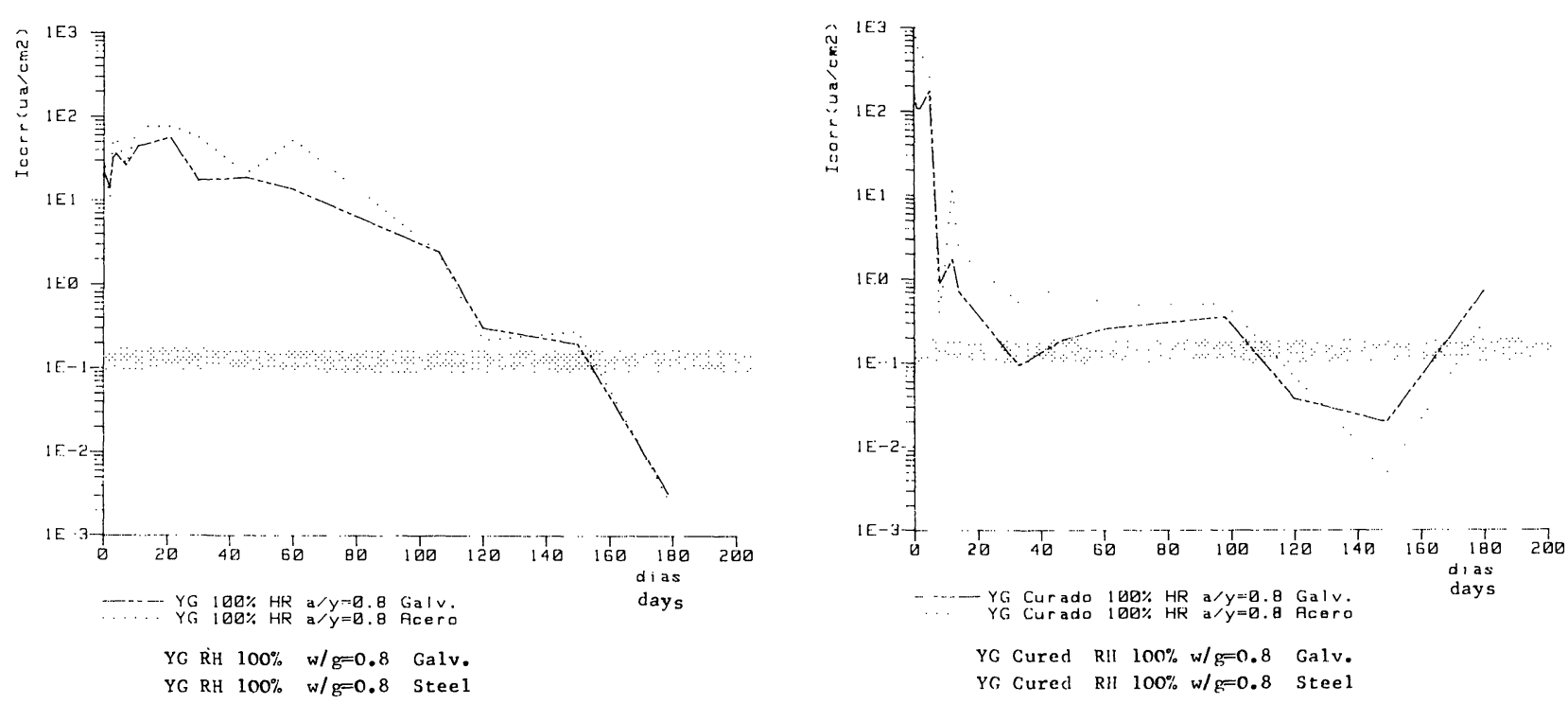

- YG Curado $100 \%$ HR $a / y=0.8$ Galv.
YG Curado $100 \%$ HR $a / y=0.8$ Acero

YG Cured RII $100 \%$ w/g $=0.8$ Galv. YG Cured RU $100 \%$ w/g $=0.8$ Steel
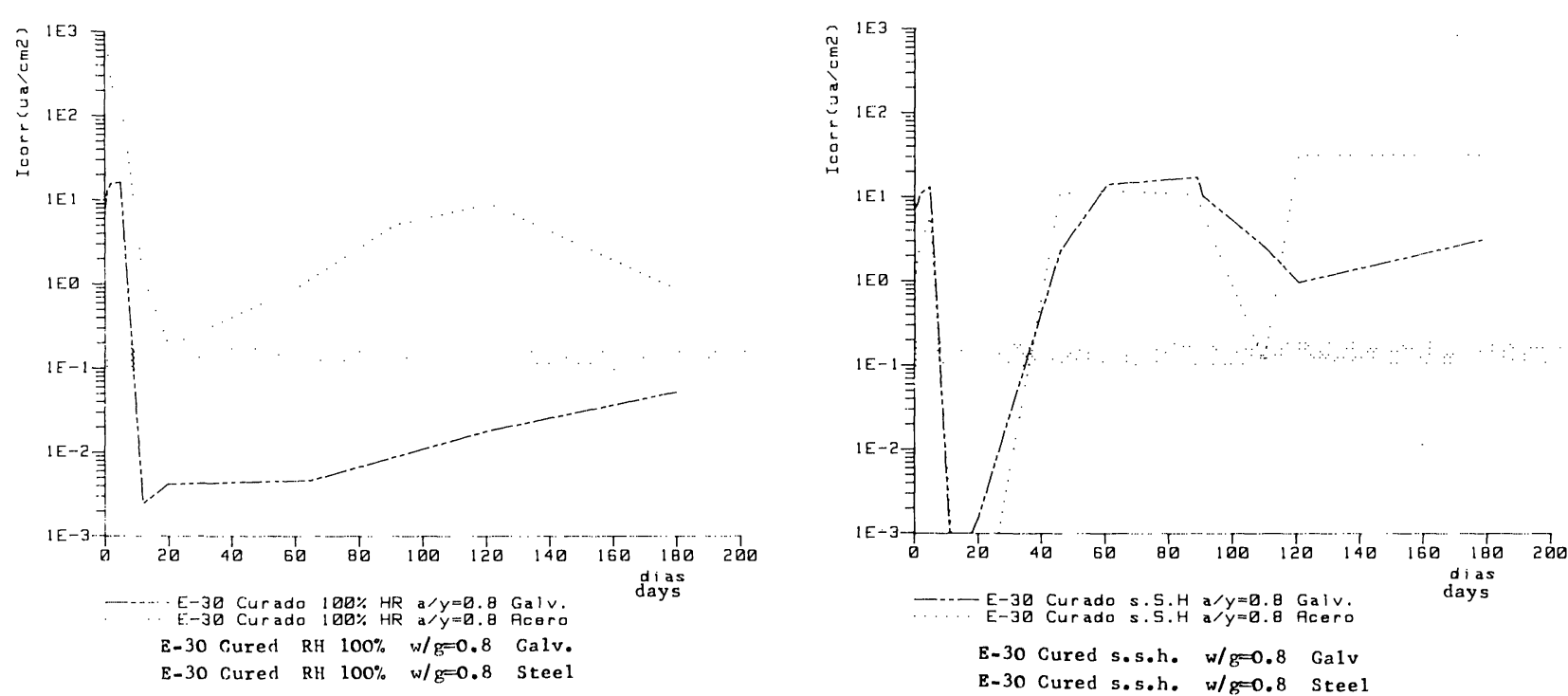

Fig. 4.-Evolución de la $\mathrm{i}_{\text {corr }}$ en función del tiempo de aceros embebidos en yeso grueso y escayola, en las condiciones que se indican en cada gráfico.

Fig. 4.- Evolution of $i_{\text {corr }}$ of steel embedded in coarse gympsum and plaster, as a function of time, at the conditions given in the figures. 
Las medidas de $R_{p}$ se hicieron dos veces el día de la confección de las probetas y después a intervalos de tiempo de $1,2,3,7$, $15,30,45,60,90,120,150$ y 180 días.

Al finalizar el ensayo se procedió a romper las probetas y fotografiarlas. Asimismo se decaparon las placas para eliminar los productos de corrosión y se pesaron con el fin
Two measurements of $R_{p}$ were made during the day of the specimen preparation and thenafter, at time periods of 1, 2, 3, 7, 15, 30, $45,60,90,120,150$ and 180 days.

At the end of the test, the specimens were broken and photographed. In addition, the plates were scaled to remove the corrosion products and weighed in order to determine
N."Placa 29

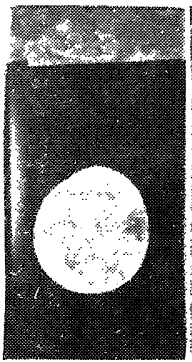

26

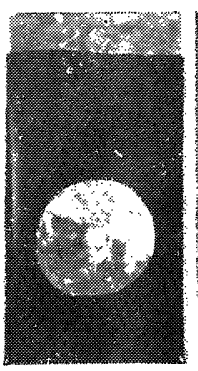

29. Galv. $50 \%$ HR $Y G a / y=0,8$

26. Acero $50 \%$ HR YG a/y $=0,8$

28
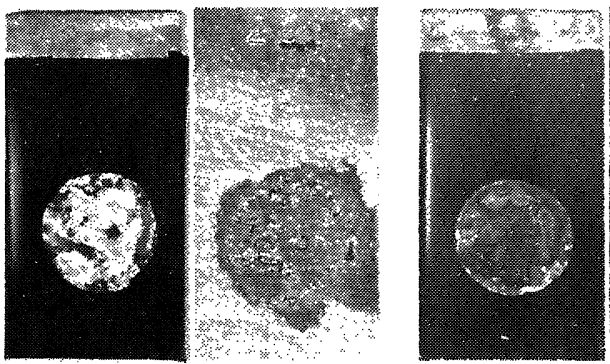

28. Galv. $100 \%$ HR YG a/y $=0,8$

25. Acero $100 \%$ HR YG a/y $=0,8$
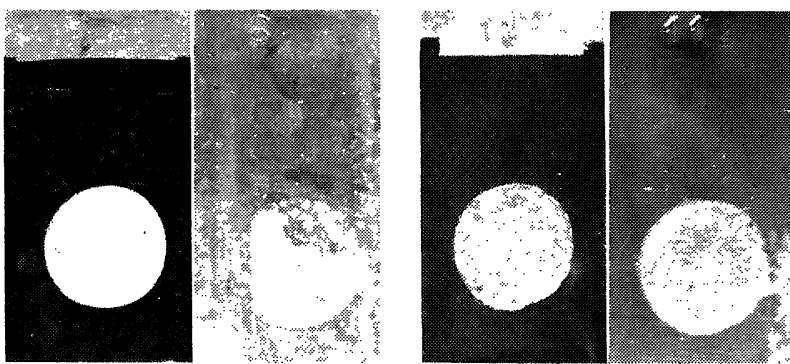

8. Galv. $100 \%$ HR E-30 a/y $=0,8$ curado

11. Acero $100 \% \mathrm{HR}$ E-30 a/y $=0,8$ curado

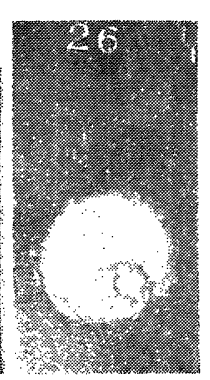

25

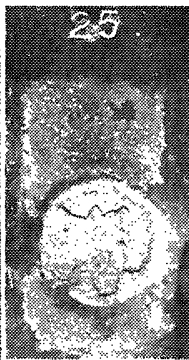

11
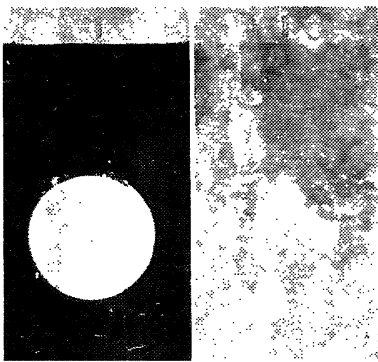

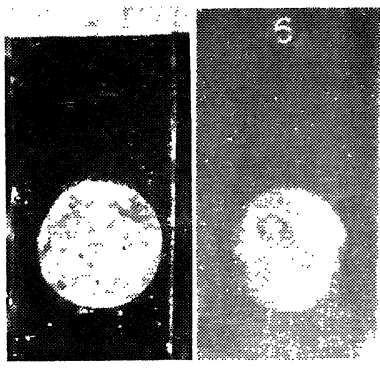

1. Galv. $50 \%$ HR YG a/y $=0,8$ curado

6. Acero $50 \%$ HR YG a/y $=0,8$ curado

46

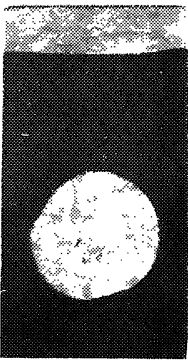

46. Galv. $100 \% \mathrm{HR}$ YG a/y $=0,8$ curado

44. Acero $100 \% \mathrm{HR}$ YG a/y $=0,8$ curado

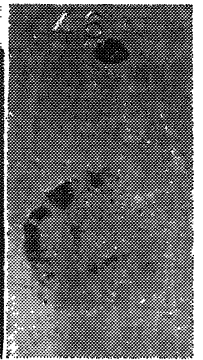

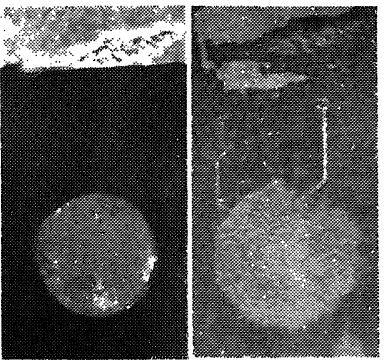
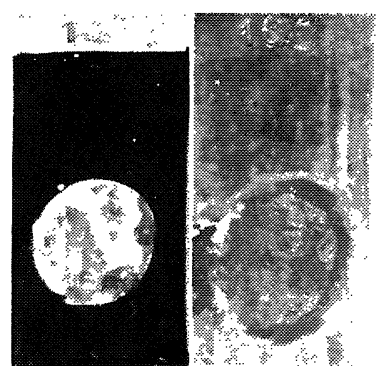

12

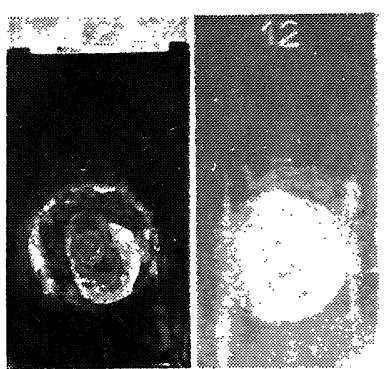

10. Galv. s.S.H. E-30 a/y $=0,8$ curado

12. Acero s.S.H. E-30 a/y $=0,8$ curado

Fig. 4A.-Aspecto de las placas al final del ensayo antes (izquierda) y después (derecha) de la eliminación de la cinta protectora y del decapado del óxido, ensayadas en yeso grueso y escayola, en las condiciones que se indican en cada caso.

Fig. 4A-Appearance of the plates at the end of the test before (left) and after (right) removal of the adhesive tape and the scaling of oxide, tested with YG and plaster at the conditions shown for each case. 
de determinar lar pérdida gravimétrica sufrida durante el proceso de corrosión.

\section{RESULTADOS}

La pérdida de peso calculada a partir de los resultados de $R_{p}$ (electroquímica), se contrastaron por vía gravimétrica, observándose buena correlación en la mayoría de los ensayos y graves discrepancias en especial en algunos casos con acero negro. Como la medida más fiable en estos estudios es la gravimétrica (excepto en algún caso que se produjo corrosión debajo de la cinta aislante y por tanto la gravimetría aparece
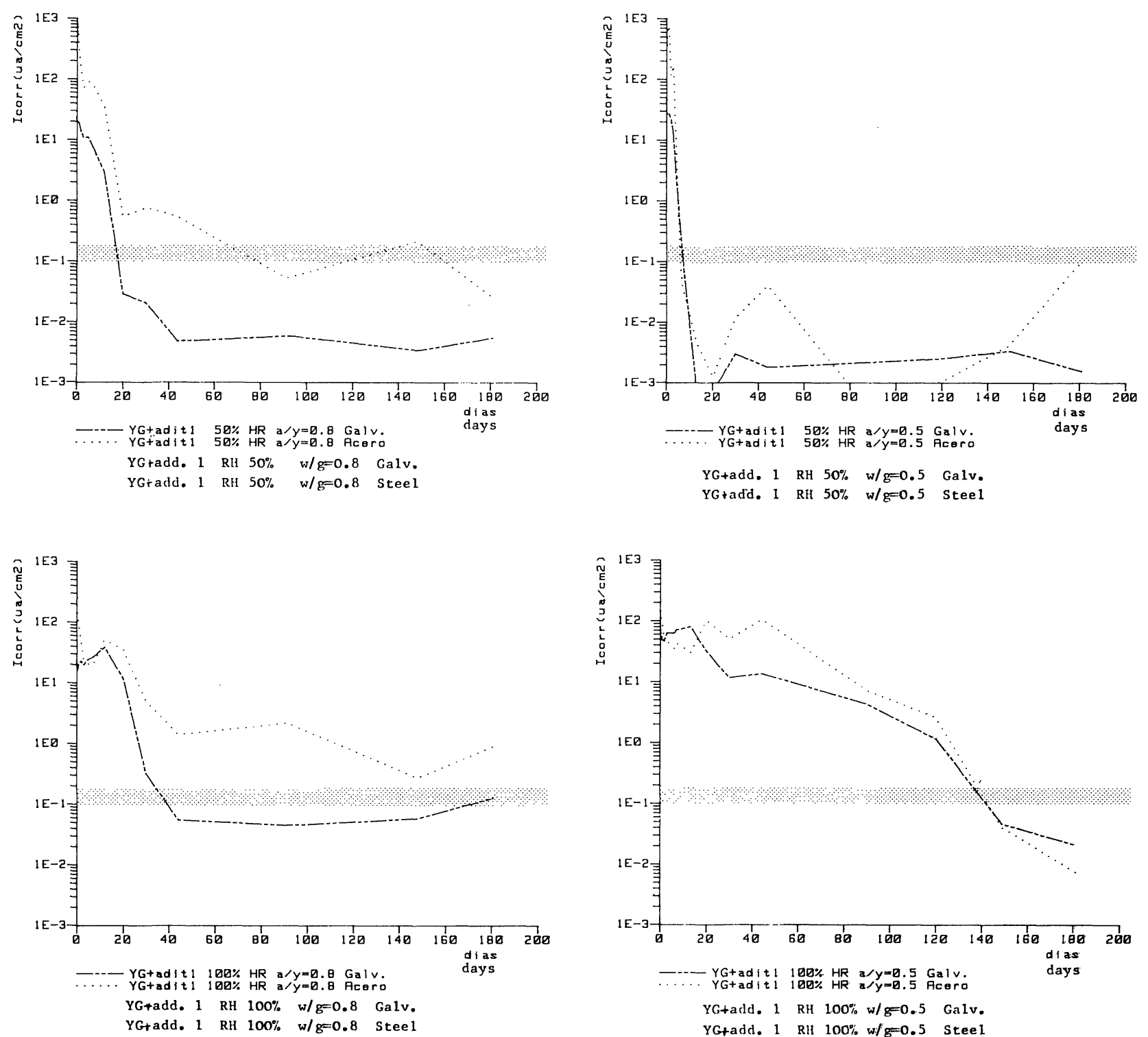

Fig. 5.-Evolución de la $i_{c o r r}$ en función del tiempo de aceros embebidos en yeso grueso con aditivo endurecedor (1); en las condiciones que se indican en cada gráfico.

Fig. 5.-Evolution of $i_{\text {corr }}$ of steel embedde in coarse gypsum with hardener additive (1), as a function of time, at the conditions given in the figures. 
con exceso), se optó por utilizar unos valores de $B$ de la fórmula de Stern ficticios, para igualar ambas pérdidas de peso. Todos los valores de $B$ adoptados se muestran para cada ensayo en la tabla 1 . Los valores de $i_{\text {corr }}$ representados en las figuras que se citan a continuación corresponden a los calculados a partir de los valores de B citados en la tabla y por tanto contrastados con las gravimetrías. En la figura 3 se han representado los valores de las pérdidas gravimétricas para todos los casos ensayados.

La figura contiene los resultados para los ensayos al $50 \%$ HR (parte superior), para aquéllos cuando las probetas se conservaron al $100 \%$ HR (parte intermedia) y cuando se conservaron sobre superficie húmeda (parte inferior).

Puede observarse que prácticamente siempre el acero desnudo se corroe más que el galvanizado, y que cuando la humedad es elevada (100\% y S.S.H.) el acero galvanizado the gravimetric losses were higher than it was expected), some fictitous $B$ values in the Stern formula were used in order to equalize both weight losses. All fictitous $B$ values adopted are shown for each test in Table 1. The $i_{\text {corr }}$ values shown in the following figures correspond to those calculated from the $B$ values given in the table and therefore, they are assayed with their gravimetric values. Fig. 3 shows all the gravimetric loss values for all cases tested.

The figure shows the results obtained for tests at $50 \%$ RH (upper), for those with specimens kept at $100 \% \mathrm{RH}$ (middle) and those kept on moist surfaces (lower).

It can be observed that bare steel always corrodes more than a galvanized one as relative humidity is increased $(100 \%$ and S.S.H.), galvanized steel, however, has relatively
N. Placa 14

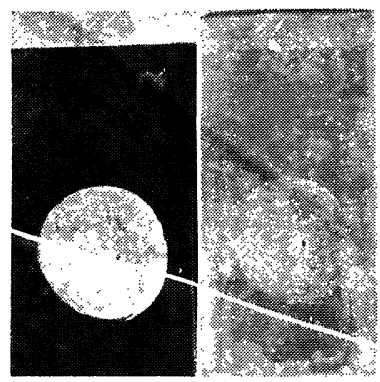

17

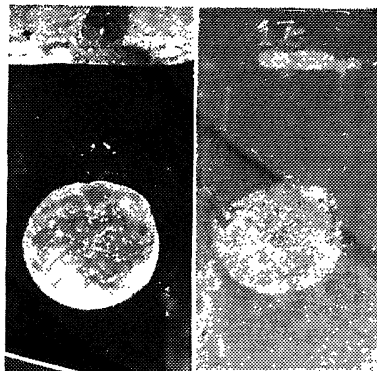

36

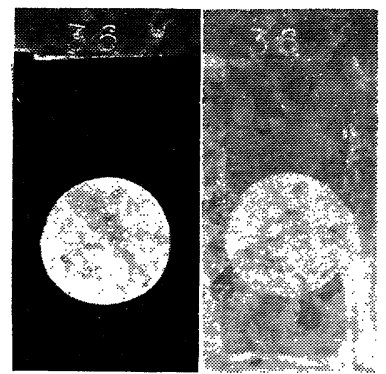

32

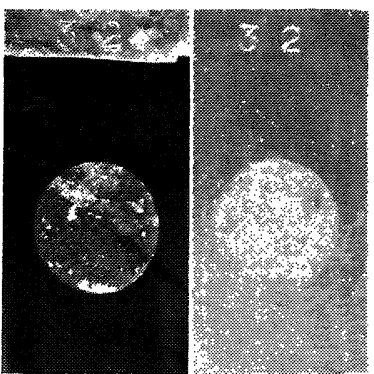

14. Galv. $50 \% H R Y G+$ adit $1 a / y=0,8$

17. Acero $50 \% \mathrm{HR} Y \mathrm{YG}+$ adit $1 \mathrm{a} / \mathrm{y}=0,8$
36. Galv. $50 \% H R Y G+$ adit $1 a / y=0,5$

32. Acero $50 \%$ HR YG + adit $1 a / y=0,5$
16

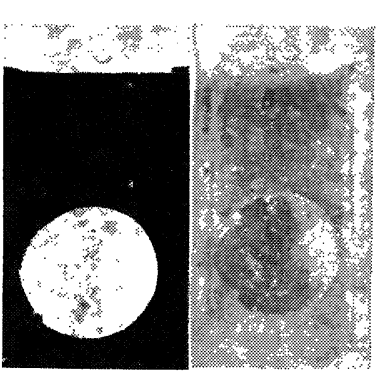

18

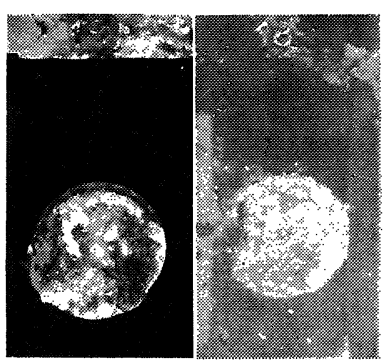

34

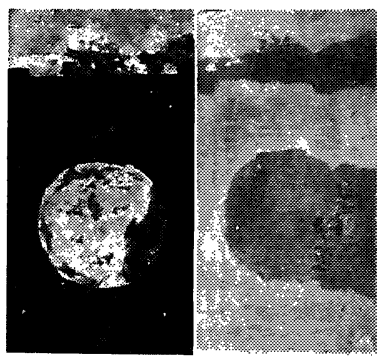

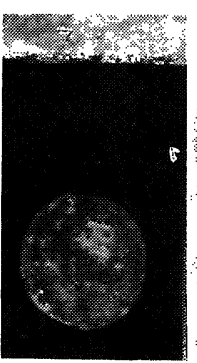

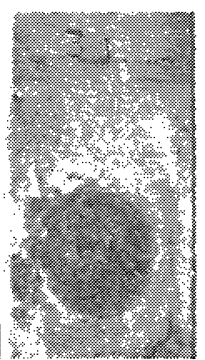

16. Galv. $100 \%$ HR YG + adit $1 \mathrm{a} / \mathrm{y}=0,8$

34. Galv. $100 \%$ HR YG + adit $1 a / y=0,5$

31. Acero $100 \% \mathrm{HR} Y \mathrm{YG}+$ adit $1 \mathrm{a} / \mathrm{y}=0,5$

Fig. 5A.-Aspecto de las placas al final del ensayo antes (izquierda) y después (derecha) de la eliminación de la cinta protectora y del decapado del óxido, ensayados en yeso con aditivo endurecedor en las condiciones que se indican en cada caso.

Fig. 5A-Appearance of the plates at the end of the test before (left) and after (right) removal of the adhesive tape and the scaling of oxide, tested with YG with hardener at the conditions shown for each case. 
también presenta corrosión relativamente elevada como era de esperar.

Los aditivos utilizados prácticamente no modifican el comportamiento, aunque el "para enfoscado" mantiene el galvanizado bastante inalterado al aumentar la humedad del $50 \%$ al $100 \%$. El curado a $42{ }^{\circ} \mathrm{C}$ tampoco altera el comportamiento global. La adición de nitrito cálcico e hidróxido cálcico en cambio, parece mejorar el comportamiento del acero galvanizado, ya que reduce también las pérdidas de peso totales.

En las figuras restantes $(4,4 \mathrm{~A}, 5,5 \mathrm{~A}, 6,6 \mathrm{~A}$, $7,7 \mathrm{~A}$ y $8,8 \mathrm{~A}$ ) se han representado las
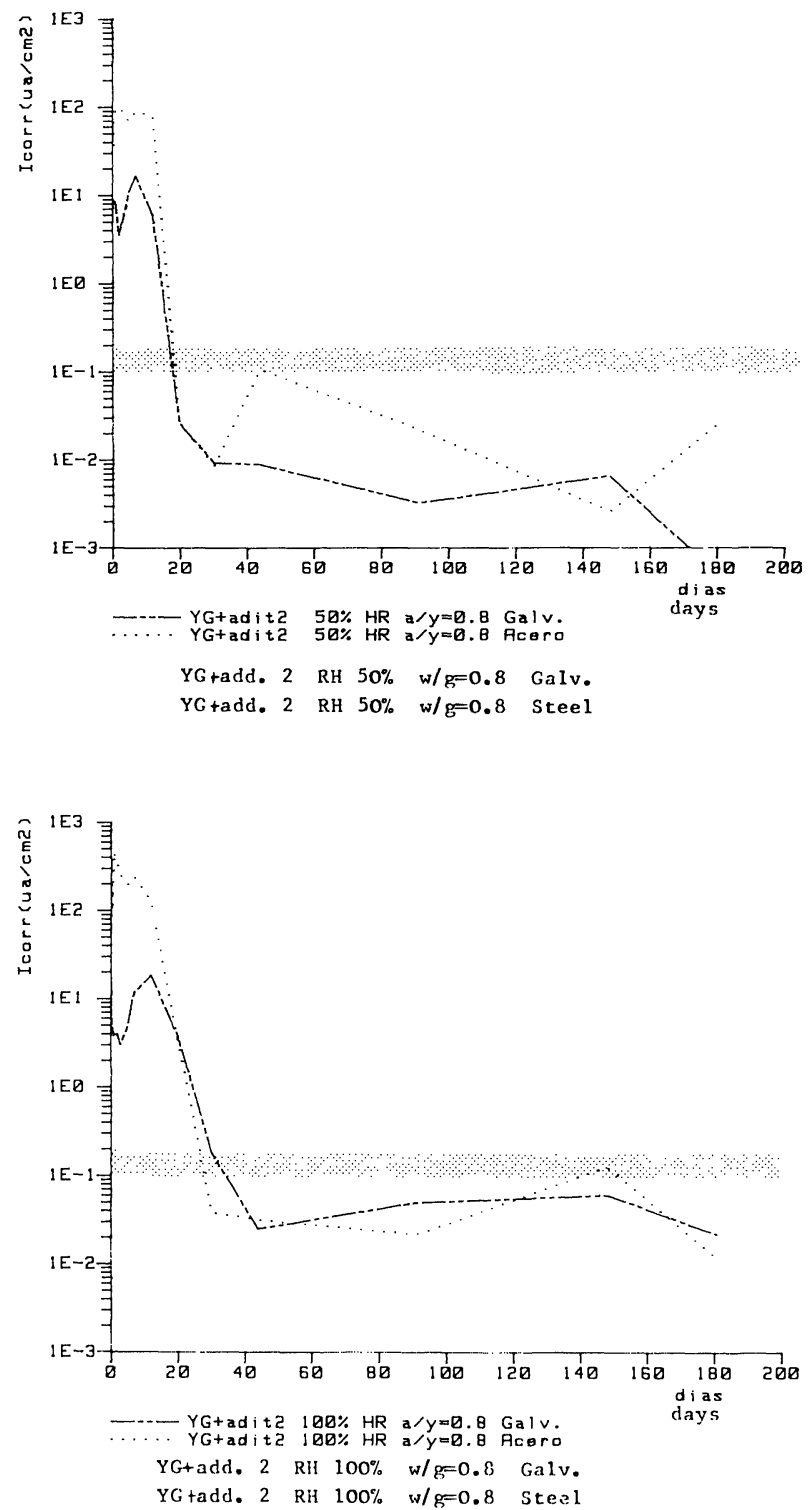

high corrosion rate as it was expected.

Additions do not noticeably modify behaviours, though for stretching additive" keeps galvanized steel quite unaltered when humidity raises from $50 \%$ to $100 \%$. Curing process at $42^{\circ} \mathrm{C}$ does not change total behaviour either. On the contrary, addition of sodium nitrite and calcium hydroxides, seems to improve the behaviour of galvanized steel, since total weight losses are reduced indeed.

Fig. 4, 4A, 5, 5A, 6, 6A, 7, 7A and 8, 8A show $i_{\text {corr }}$ variations along time, as well as the
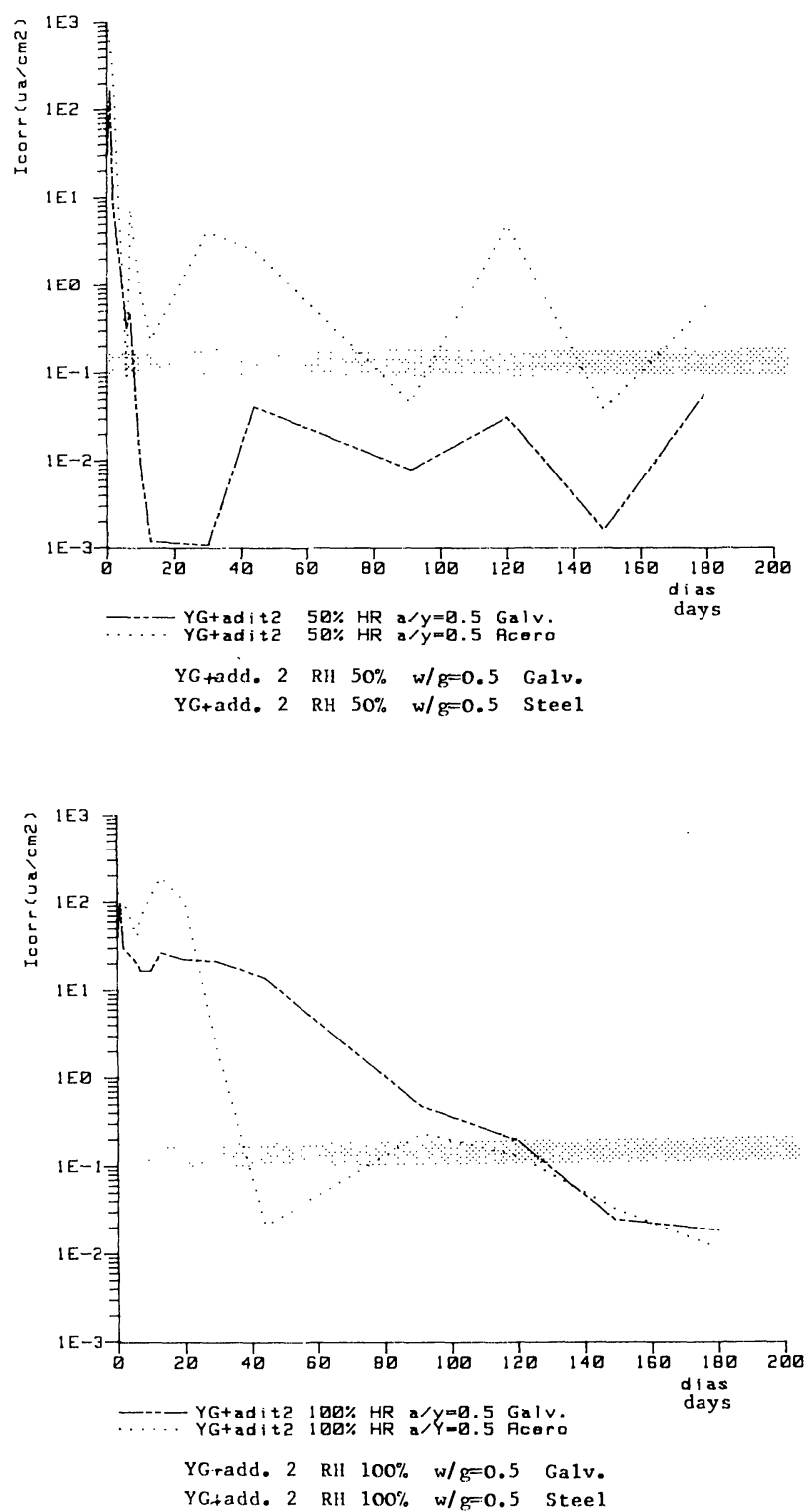

Fig. 6.-Evolución de la $i_{\text {corr }}$ en función del tiempo de aceros embebidos en yeso grueso con aditivo para enfoscado (2), en las condiciones que se indican en cada gráfico.

Fig. 6.-Evolution of $i_{\text {corr }}$ of steel embedded in coarse gypsum with stretching additive (2), as a function of time, at the conditions given in the figures. 
variaciones de la $i_{\text {corr }}$ con el tiempo, así como el aspecto que ofrecían al final del ensayo algunas de las placas. Las condiciones correspondientes a cada una de las figuras se detalla al pie de cada una de ellas. La zona sombreada entre 0,1 y $0,2 \mu \mathrm{A} / \mathrm{cm}^{2}$ es la que la experiencia ha señalado como frontera entre una corrosión significativa en términos de disminución de la vida útil y una corrosión tolerable.

La evolución de la $i_{\text {corr }}$ en el tiempo permite reflejar los pormenores del proceso. Así por ejemplo en las figuras 4 y 8 se puede comprobar cómo el curado a $42{ }^{\circ} \mathrm{C}$ hace descender bruscamente la velocidad de corrosión, debido al secado que introduce. También puede seguirse, cómo en el momento del amasado, casi todas las velocidades de corrosión se sitúan en valores similares, entre 20 y $30 \mu \mathrm{A} / \mathrm{cm}^{2}$ para el acero galvanizado y alrededor de un orden de magnitud superior para el acero desnudo. appearance of some plates at the end of the tests. Below each figure the corresponding conditions are detailed. The shadowed zone between 0.1 and $0.2 \mu \mathrm{A} / \mathrm{cm}^{2}$ is the frontier experimentally obtained between a significant corrosion in terms of decrease of working life and a tolerable corrosión.

The evolution of $i_{\text {corr }}$ along time provides detailed information of the processes. Thus, for instance, Fig. 4 and 8 show how curing treatment at $42^{\circ} \mathrm{C}$ produces sharp falls of the corrosion rate, due to the drying treatment applied. It can also be deduced how during the mixing almost all corrosion rates have similar values, around 20 and $30 \mu \mathrm{A} / \mathrm{cm}^{2}$ for galvanized steel and one order higher for bare steel.
N. Placa

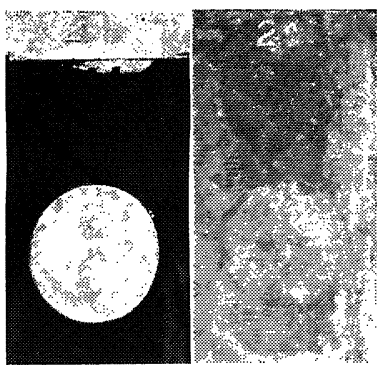

24

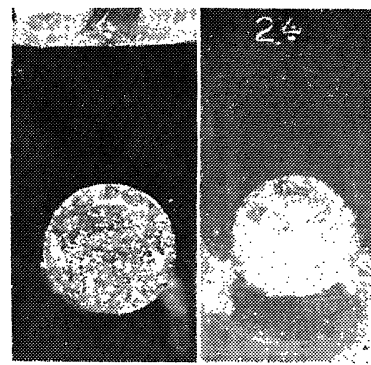

41

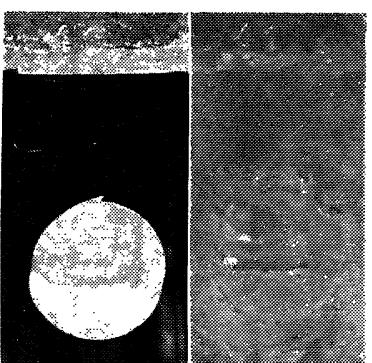

38

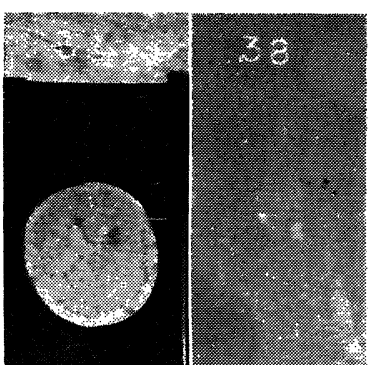

21. Galv. $50 \% H R Y G+$ adit $2 a / y=0,8$

24. Acero $50 \% H R Y G+$ adit $2 a / y=0,8$
41. Galv. $50 \% H R Y G+$ adit $2 a / y=0,8$

38. Acero $50 \% \mathrm{HR} Y \mathrm{YG}+$ adit $2 \mathrm{a} / \mathrm{y}=0,5$
19

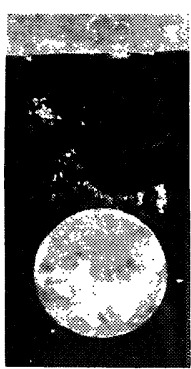

23

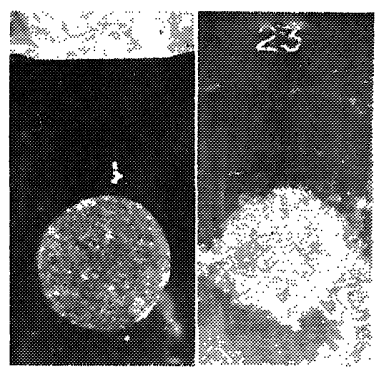

40

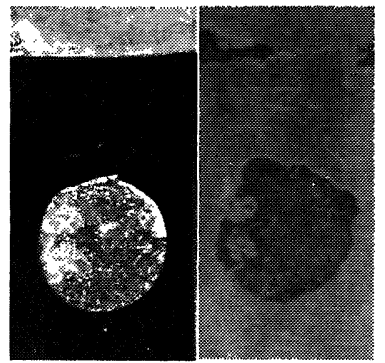

37

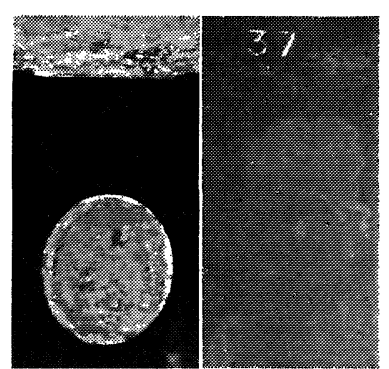

19. Galv. $100 \% H R Y G+$ adit $2 a / y=0$

40. Galv. $100 \% \mathrm{HR} Y \mathrm{G}+$ adit $2 \mathrm{a} / \mathrm{y}=0,5$

37. Acero $100 \% \mathrm{HR} Y G+$ adit $2 a / y=0,5$

Fig. 6A.-Aspecto de las placas al final del ensayo, antes (izquierda) y después (derecha) de la eliminación de la cinta protectora y del decapado del óxido, ensayadas en yeso con aditivo para enfoscado (2), en las condiciones que se indican en cada caso.

Fig. 6A-Appearance of the plates at the end of the test before (left) and after (right) removal of the adhesive tape and scaling of oxide, tested with gypsum and stretching additive at the conditions shown for each case. 
Con posterioridad es determinante la humedad ambiental en el caso del yeso sin aditivos o con los aditivos 1 y 2 , produciéndose descensos de 2 a 4 órdenes de magnitud en la $i_{\text {corr }}$ cuando la humedad es del $50 \%$. También es de destacar que las probetas amasadas con una relación $a / y=0,5$ y conservadas al $100 \% \mathrm{HR}$, sólo presentan un descenso en la $\mathrm{i}_{\text {corr }}$ al cabo de 120-140 dias del ensayo, mientras que las que fueron fabricadas con una relación $a / y=0,8$ presentan este descenso de la $\mathrm{i}_{\text {corr }}$ mucho más tempranamente (entre los 20 y 40 días).

En cuanto al comportamiento de los nitritos hay que destacar que tanto los valores de la $\mathrm{i}_{\text {corr }}$ detectados como el aspecto visual que
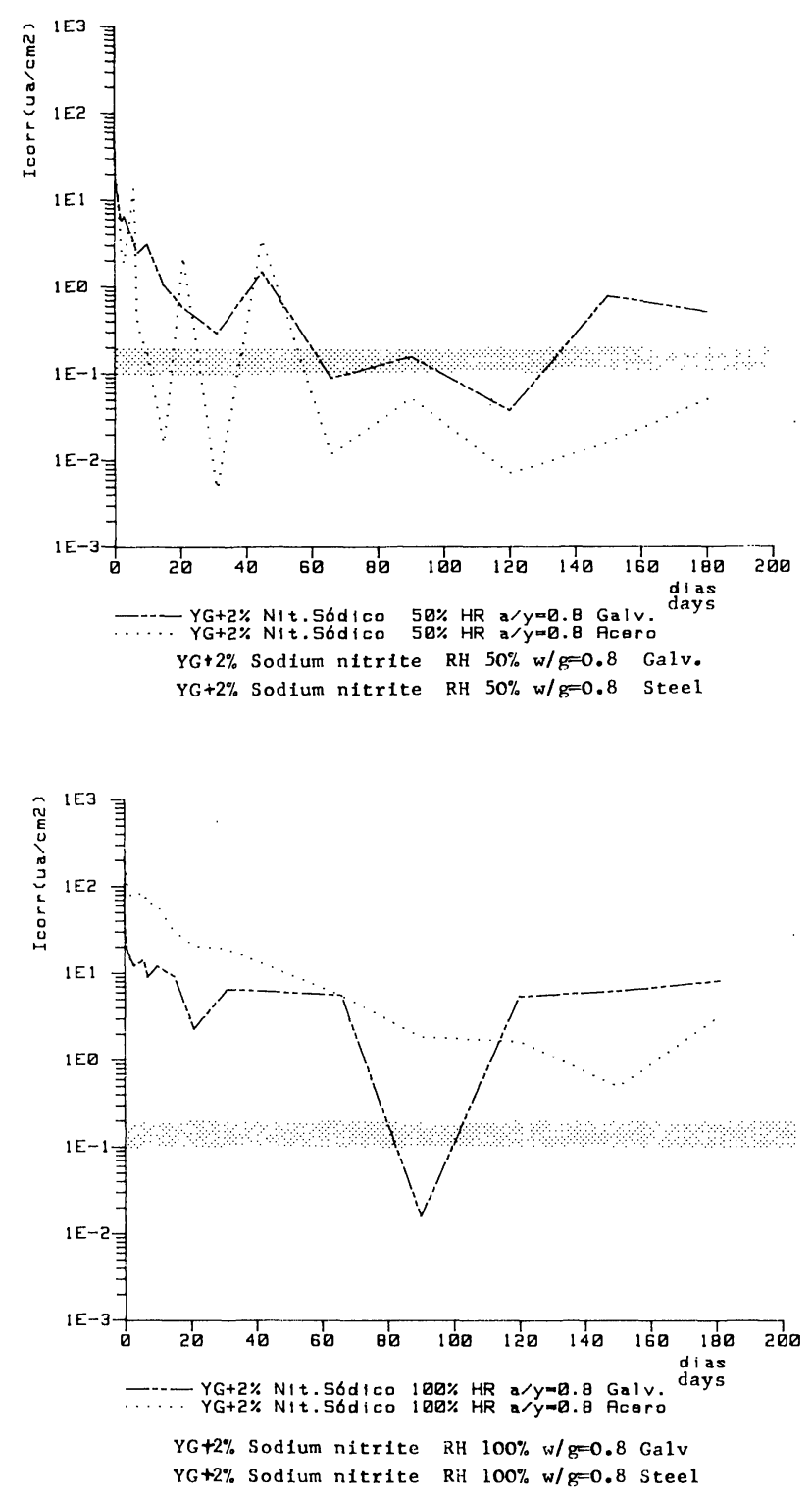

Envirometal humidity in the case of gypsum without additions or with additions 1 and 2 is very important later. Humidity of $50 \%$ produces falls from 2 to 4 order of $i_{\text {corr }}$. It is also remarkable that specimens prepared with $w / g$ ratio 0.5 and kept at $100 \% \mathrm{RH}$ have a fall of $i_{\text {corr }}$ only after 120-140 days, while those made with a $w / g$ ratio 0.8 have much earlier falls (between 20 and 40 days).

In relation to nitrite behaviour, it should be pointed out that both $i_{\text {corr }}$ values obtained visual specimen appearances show that
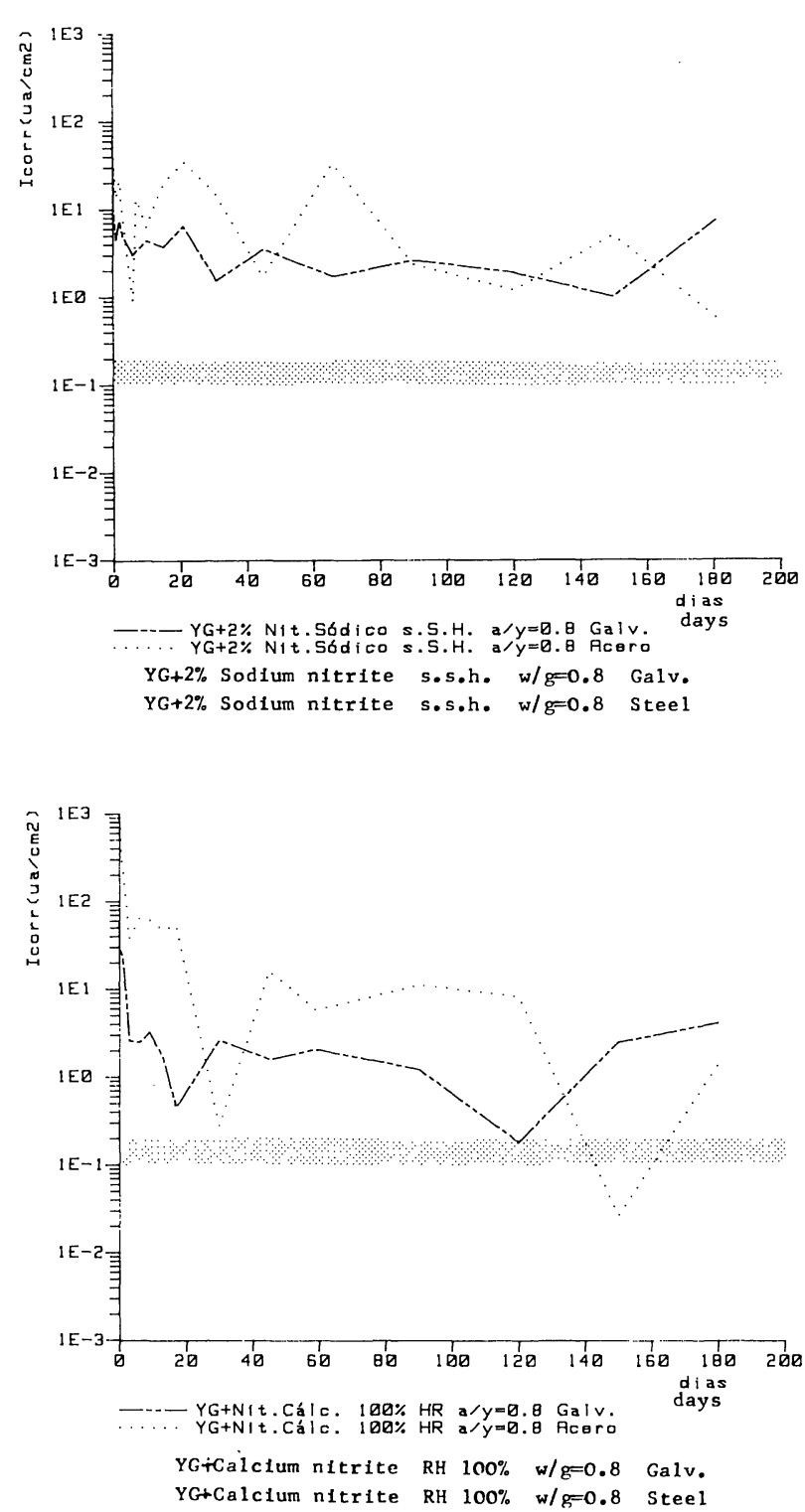

Fig. 7.-Evolución de la $\mathrm{i}_{\text {corr }}$ en función del tiempo de aceros embebidos en yeso grueso con adición de nitrito sódico y nitrito cálcico en las condiciones que se indican en cada gráfico.

Fig. 7.-Evolution of $i_{\text {corr }}$ of steel embedded in coarse gypsum with addition of sodium and calcium nitrite, as a function of time, at the conditions given in the pictures. 
ofrecen las probetas, indican que mejoran enormemente el comportamiento del acero sin proteger e incluso el del acero galvanizado. Es en este caso cuando aparecen las mayores discrepancias con los datos obtenidos en la gravimetría. Una explicación podría estar en que en algunas de las plaquitas se observó una corrosión en el borde de la cinta aislante (placa no 69). En todo caso el examen visual no muestra signo alguno de corrosión en las placas $n^{\circ} 55$ y n० 56 .

Algo similar aunque menos llamativo ocurre cuando se añade cal, en que las medidas electroquímicas y el examen visual no concuerdan con las gravimétricas. La adición de cal parece mejorar el comportamiento de ambos aceros, si bien su uso no se recomienda al aparecer fenómenos definidos de expansión que agrietan enormemente las probetas como se puede apreciar en la figura 9 . behaviours of bare steels and even galvanized ones are remarkably improved. It is in this case, however, when the largest discrepancies with data obtained by gravimetric measurements are observed. Explanation migh: be found in some plates on which corrosion near the adhesive tape border occured (plate num. 69). Anyway, visual examination on plates num. 55 and 56 did not show any marks of corrosion.

Something similar but less remarkable takes place when lime is added, in which case the electrochemical measurements and visual examinations do not agree with those obtained gravimetrically. Lime addition seems to improve the behaviour of both steels, though its employment is not recommended due to some expansion phenomena that may remarkably crack specimens as shows fig. 9.
N. Placa 59
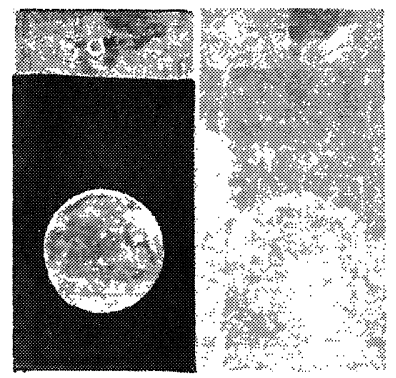

56

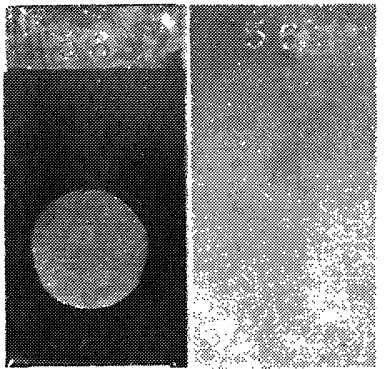

59. Galv. $50 \%$ HR YG $+2 \%$ Nit. Sod. $a / y=0,8$

59. Acero $50 \%$ HR YG $+2 \%$ Nit. Sod. $a / y=0,8$
64
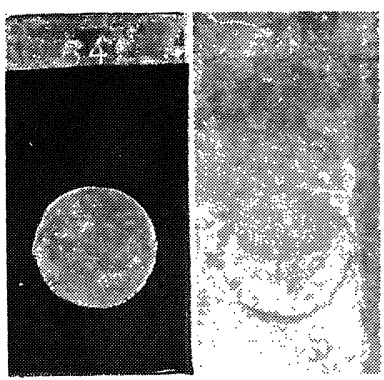

61
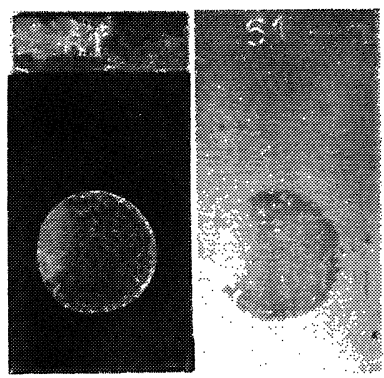

64. Galv. sSH YG $+2 \%$ Nit. Sod. $a / y=0,8$

61. Acero sSH YG $+2 \%$ Nit. Sod. $a / y=0,8$

68

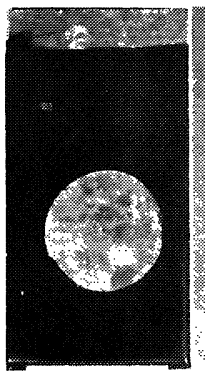

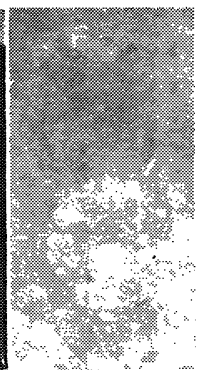

69

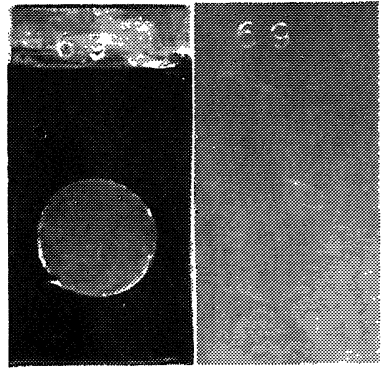

68. Galv. $100 \%$ RG YG $2 \%$ Nit. Cal. $a / y=0,8$

69. Acero $100 \%$ RG YG $2 \%$ Nit. Cal. $a / y=0,8$

66. Galv. $100 \%$ HR YG $+2 \%$ Nit. Sod. $a / y=0,8$
62. Acero $100 \%$ HR YG $+2 \%$ Nit. Sod. $a / y=0,8$

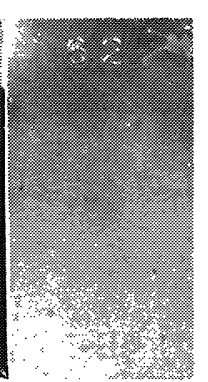

Fig. 7A.-Aspecto de las placas al final del ensayo, antes (izquierda) y después (derecha) de la eliminación de la cinta protectora y del decapado del óxido, ensayadas en yeso en adición de nitrito sódico y nitrito cálcico, en las condiciones que se indican en cada caso.

Fig. 7A-Appearance of the plates at the end of the test before (left) and after (right) removal of the adhesive tape and scaling of oxide, tested with gypsum and additions of sodium and calcium nitrite, at the conditions given in the figures. 


\section{DISCUSION Y CONCLUSIONES}

Como era de esperar el yeso induce una corrosión muy notable en el acero desnudo en cualquier humedad de conservación. En cambio el acero galvanizado se mantiene dentro de los límites de una corrosión tolerable cuando el yeso se encuentra seco, pasando a presentar cinéticas de disolución significativas cuando el yeso se humedece. Así pues ambos metales no son recomendables para su uso en contacto con yeso si no se toman medidas adicionales de protección. La adición de aditivos al yeso no modifica este comportamiento.
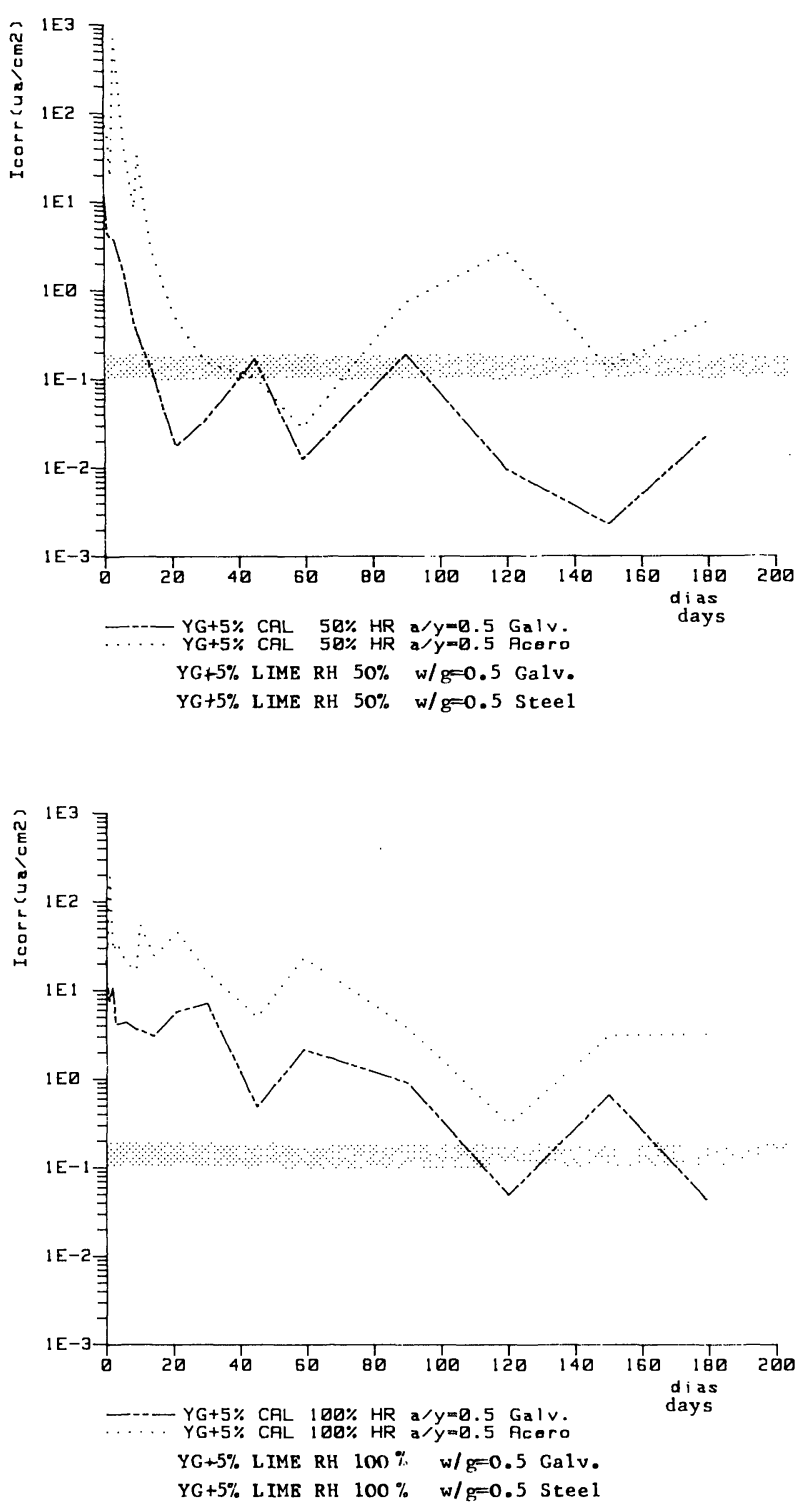

\section{DISCUSSION AND CONCLUSIONS}

As it was expected gypsum induces remarkable corrosion in bare steel at any storage humidity. On the contrary, galvanized steel remains between tolerable corrosion limits when gypsum is dry, while it has a significant solution kinetics when gypsum becomes wet. Therefore, both metals are not recommended for use in contact with gypsum, unless, additional protecting measures are taken. Additions to gypsum do not modify this behaviour.
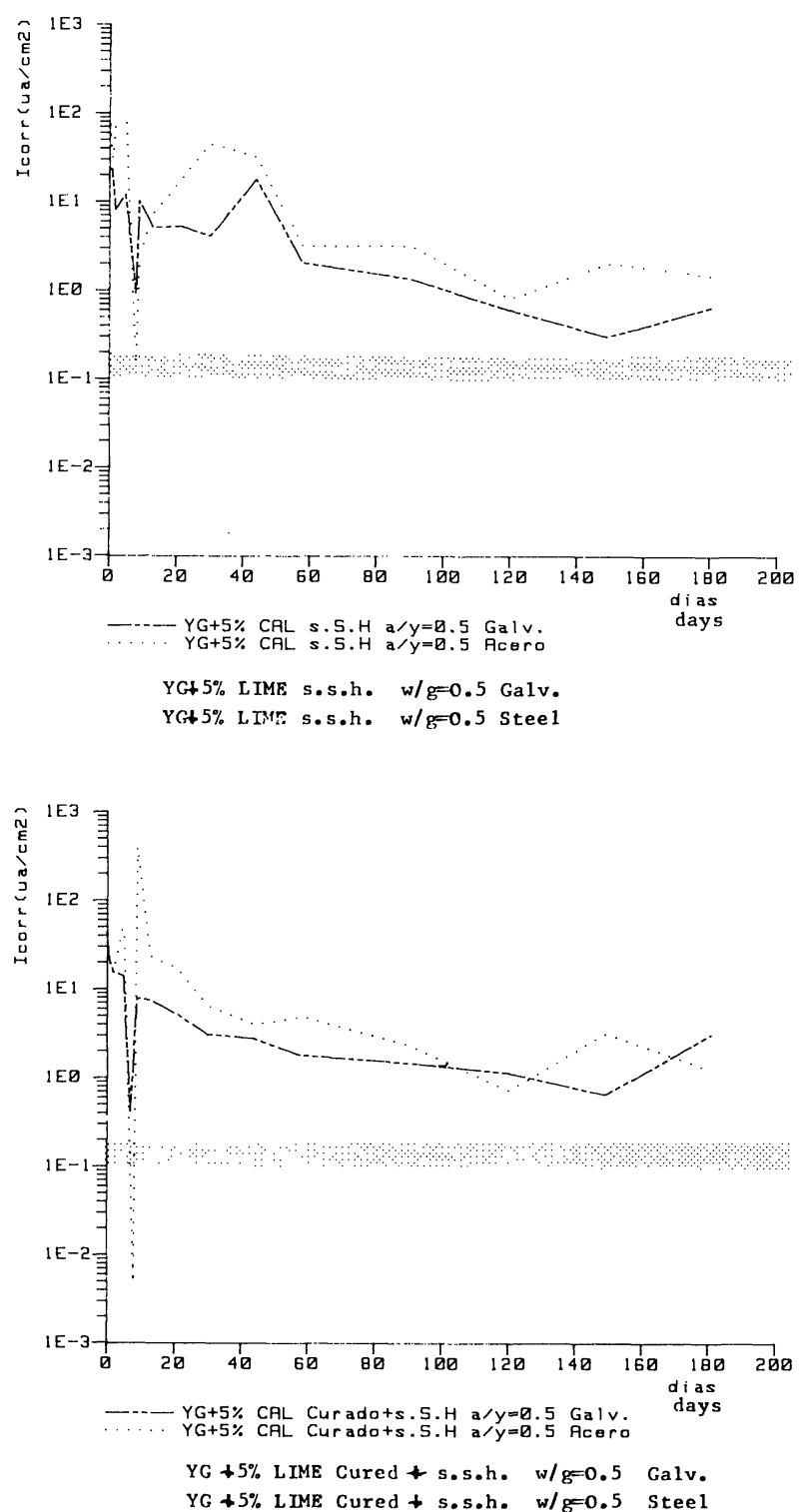

Fig. 8.-Evolución de la $i_{\text {corr }}$ en función del tiempo de aceros embebidos en yeso grueso con adición de hidróxido cálcico, en las condiciones que se indican en cada gráfico.

Fig. 8.-Evolution of $i_{\text {corr }}$ of steel embedded in coarse gypsum with addition of calcium hydroxide, as a function of time, at the conditions given in the figures. 
El secado a $42{ }^{\circ} \mathrm{C}$ resulta siempre beneficioso ya que seca las probetas bruscamente y acelera por tanto el descenso de la velocidad de corrosión. Ahora bien, si con posterioridad el yeso vuelve a conservarse en elevadas humedades, este beneficio es simplemente pasajero. En cuanto a la relación $a / y$, en los presentes ensayos ha resultado más favorable usar la de 0,8 que prescribe la orma UNE que la de 0,5 , a pesar de que esta última permite un endurecimiento más rápido.

El empleo de cal no se recomienda en absoluto a pesar de la mejora que produce en la corrosión debido al carácter alcalino que confiere al medio. Los fenómenos diferidos de expansión que provocan la hacen desaconsejable.

En cambio los nitritos mejoran claramente el comportamiento del acero negro y pueden ser una solución en algunas circunstancias. Su
Drying treatment at $42^{\circ} \mathrm{C}$ is always favourable as specimens are suddenly dried and therefore accelerates the decrease of the corrosion rate. Nevertheless, if gypsum is kept again at high humidity rates after drying treatment advantages are only trasitory. In relation to $\mathrm{w} / \mathrm{g}$ ratio, these tests have shown betters results with 0.8, as it is prescribed in UNE standard, than with 0.5, though the latter allows an earlier hardening.

The use of lime is not recommended at all, in spite of the improvement it induces on corrosion due to the alkaline character induced to the medium. Its use is not advisable due to delayed expasion phenomena.

On the contrary, nitrite addition clearly improves the behaviour of black steel and may become a solution under certain
N. Placa 48
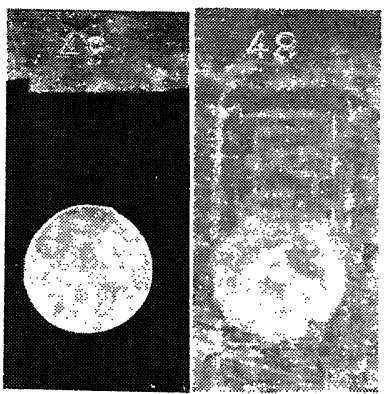

45

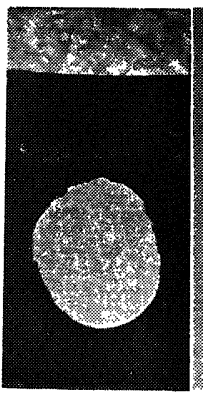

48. Galv. $50 \%$ HR YG $+5 \% \mathrm{CAL} a / y=0,5$

45. Acero $50 \% \mathrm{HR}$ YG $+5 \% \mathrm{CAL} a / y=0,5$
49

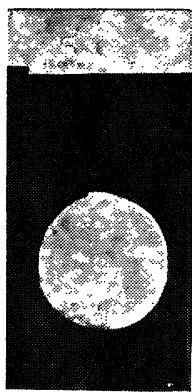

51

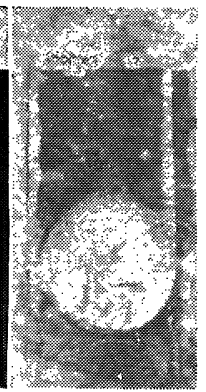

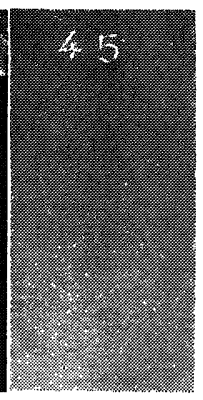

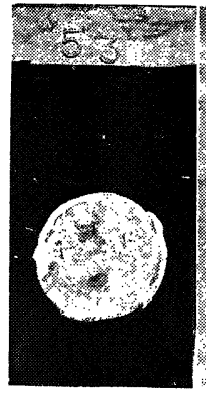

53

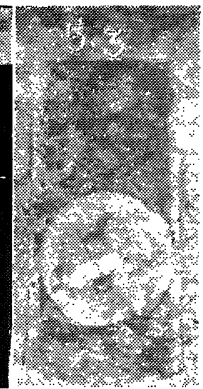

50

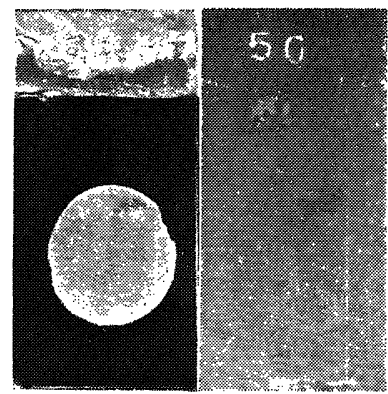

53. Galv. $s S H Y G+a / y=0,5$

50. Acero $s S H Y G+a / y=0,5$

58

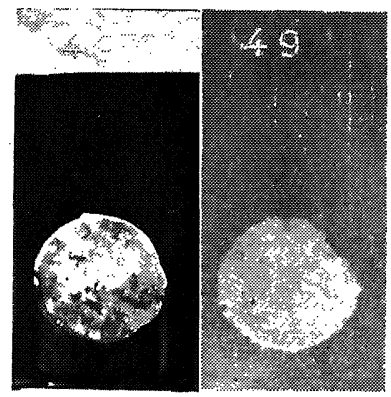

51. Galv. $100 \% \mathrm{HR}$ YG $+5 \% \mathrm{CAL} a / y=0,5$

49. Acero $100 \% \mathrm{HR} Y \mathrm{YG}+5 \% \mathrm{CAL} a / y=0,5$

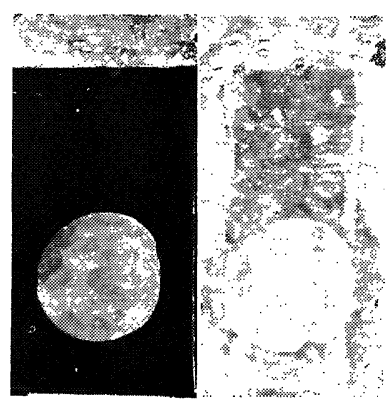

55

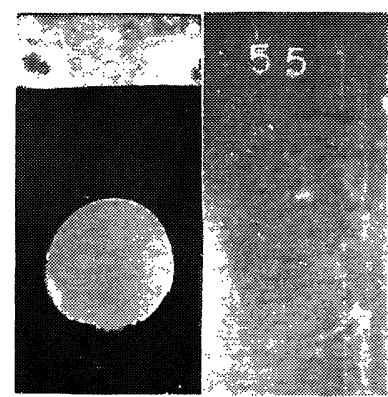

58. Galv. $s S H ~ Y G+5 \% C A L ~ a / y=0,5$ curado

55. Acero sSH YG $+5 \% \mathrm{CAL} a / y=0,5$ curado

Fig. 8A.-Aspecto de las placas al final del ensayo, antes (izquierda) y después (derecha) de la eliminación de la cinta protectora y del decapado del óxido, ensayadas en yeso con adición de hidróxido cálcico, en las condiciones que se indican en cada caso.

Fig. 8A-Appearance of the plates at the end of the test before (left) and after (right) removal of the adhesive tape and scaling of oxide, tested with gypsum and addition of calcium hydroxide, at the conditions given in the figures. 
presencia no modifica o mejora ligeramente sólo el comportamiento del galvanizado.

En cuanto a las técnicas de medida utilizadas la no concordancia entre los valores de $i_{\text {corr }}$ obtenidos mediante la $R_{p}$ y las de pérdida de peso obtenidos por gravimetria se ha producido fundamentalmente en el caso del acero negro sin que se haya podido encontrar una explicación satisfactoria a este fenómeno. En cualquier caso, dado que su exactitud puede ser siempre contrastada con la gravimetria, las medidas de $R_{p}$ aportan siempre mayor información sobre el transcurso del proceso. circunstances. Additions of nitrites do not modify or slightly improve the behaviour of galvanized steel.

In relation to the measurement technics employed, the discrepancies found between the $i_{\text {corr }}$ values obtained by $R_{p}$ and the weight losses obtained by gravimetry have been mainly found in the black steel case and no satisfactory explanation has been found. Anyway, as their accuracy may be assayed by gravimetric measurements, $R_{p}$ measurements always provide more information of the process development.

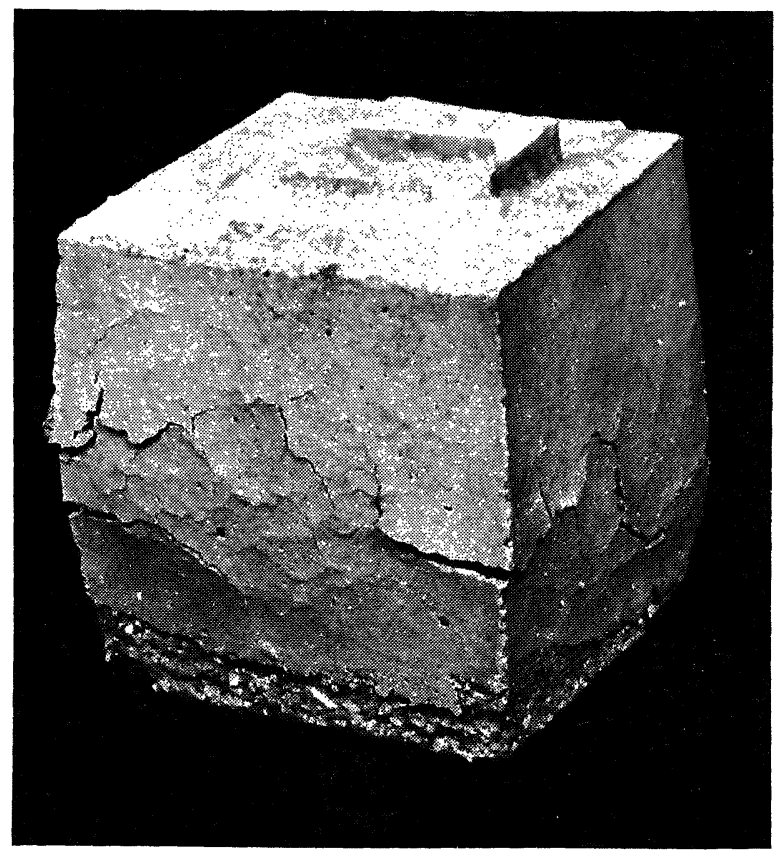

Fig. 9.-Probeta de yeso grueso con adición de hidróxido cálcico al final del ensayo efectuado sobre superficie húmeda. Puede apreciarse el agrietamiento producido por expansión.

Fig. 9.-Coarse gypsum specimen with addition of calcium hydroxide at the end of the test carried out on a moist surface. Cracks produced by expansion process can be observed.

\section{AGRADECIMIENTOS}

Las autoras agradecen a M. J. Guinea y P. Díaz Romeral del IETcc la ayuda prestada en la realización de este trabajo.

\section{ACKNOWLEDGMENTS}

We are especially grateful to $M$. J. Guinea and $P$. Díaz Romeral, IETCC, for their cooperation in this work.

\section{BIBLIOGRAFIA}

(1) Pliego General de Condiciones para la recepción de yesos y escayolas en las obras de construcción RY-85 (B.O.E. número 138,10 junio 1982).

(2) M. FOUCAULT: Collq. Int. RILEM (1977) 489.

(3) C. ANDRADE y J. GONZALEZ: Werkstoffe u. Korros. 29 (1978) 515.

(4) C. ANDRADE, V. CASTELO, C. ALONSO y S. M. GONZALEZ: Corrosion of rebars in concrete. Edt. 4 Chaker, ASTM 906 (1986) 48.

(5) UNE 102.031.82: Yesos y escayolas de construcción. Métodos de ensayos físicos y mecánicos.

(6) J. A. GONZALEZ y J. FULLEA: Corr. y Prot. 5 (1974), 273.

(7) M. STERN y A. J. GEARY: J. Electrochem, Soc. 104 (1957) 56. 